\title{
The determination of the leisure orientation of university students and the investigation of the purpose of social network uses by various variables
}

\author{
Hakan Salim ÇAĞLAYAN ${ }^{1}$,Nazli Deniz ÖZ ${ }^{2}$, Abdil ARI ${ }^{1}$ \\ ${ }^{1}$ SelcukUniversity, Faculty of Sports Sciences, Department of Sport Management, Konya, Turkey. \\ ${ }^{1}$ SelcukUniversity, Faculty of Sports Sciences, Department of Recreation, Konya, Turkey. \\ Address Correspondence to ND, Oz, e-mail: denizyilmaz@selcuk.edu.tr
}

\begin{abstract}
The aim of this study is to determine the purpose of using social networking sites for university students. The universe of our search; Seljuk University and the research is composed of 309 students studying in Seljuk University at the different faculties during 2017-2018 education periods. Demographic information form including the questions determined by the researchers and Social Network Sites Usage Scale (8) were used as the data collection tool in the research. In the analysis of the datas, the relevance of normal distribution was tested according to the variables independent $t$ test for binary comparisons and and the non-parametric tests for multiple comparisons without normal distribution relevance Kruskall Wallis test was used. Significance level in the study was taken as 0.05 . In conclusion, while there was no difference according to gender, age SASKA variable scale according to the "recognition and for self-promotion" in the lower size 18-20 age group is in favor. According to the class variable, there was a difference between all the other classes in the sub-dimension for "recognition and selfpromotion in favor of the 2nd grade. According to the monthly income variable, in the sub-dimension "recognition and selfpromotion", significant results were found in favor of 1501 and above income group $(\mathrm{p}<0.05)$.
\end{abstract}

Keywords: Use of Social Network Sites, University Student, Social Media

\section{INTRODUCTION}

Social networking sites are web-based services that allow individuals to create a public or semiopen profile within a defined system, display a list of other users to whom they are linked, this allows other users to see the listed connections on the system and web-based services that allow these connections to switch between them (3). Social networking sites are defined as "software that facilitate the interaction between individuals and groups, offer a variety of options for social feedback and support the formation of social relations" $(7,9)$. These structures; it enables users to communicate with each other in online social communities, and to communicate with other users with common interests or common features, it also helps users publish photos, files, personal work and information online and even organize online organizations (6).

Although social networks can communicate with friends, make new friends, reach old friends, photos, videos, articles, etc. social networks can also be considered as a tool that can be used in education, although it is seen as structures that allow them to share various documents and share their thoughts with others (5).

Social networks, which have many features that respond to the users' requests in the Internet environment, are the most preferred sites by Internet users. Social networking sites, where members of different cultures and different geographies can be used at no cost, have brought different levels of communication and interaction between people. Social networking sites that can share all kinds of files, from photo and file sharing to educational software, visual training sets, can combine their members with a common interest in a group (13).

\section{MATERIAL \& METHOD}

The universe of the research; its sample consists of 309 students studying at different faculties during 2017-2018 academic year at Selcuk University.

The demographic information form and the Social Network Sites Intended Purpose Scale were used as data collection tools (8). In the analysis of the data, normal distribution was tested according to variables and Independent $\mathrm{t}$-test was used for 
pairwise comparisons and Kruskall Wallis test was used for non-parametric tests. The significance level was taken as 0.05 .

\section{FINDINGS}

Table.1 Demographic Information of Participants

\begin{tabular}{|c|c|c|c|}
\hline & & $\mathrm{N}$ & $\%$ \\
\hline \multirow[b]{2}{*}{ Gender } & Female & 106 & 34.3 \\
\hline & Male & 203 & 65.7 \\
\hline \multirow[b]{3}{*}{ Age } & $18-20$ age & 90 & 29.1 \\
\hline & $21-23$ age & 189 & 61.2 \\
\hline & 24 and above & 30 & 9.7 \\
\hline \multirow{4}{*}{ Class } & 1 & 34 & 11.0 \\
\hline & 2 & 78 & 25.2 \\
\hline & 3 & 90 & 29.1 \\
\hline & 4 & 107 & 34.6 \\
\hline \multirow{4}{*}{ Weekly Free Time } & 1-3 hours & 46 & 14.9 \\
\hline & 4-6 hours & 89 & 28.8 \\
\hline & $7-9$ hours & 73 & 23.6 \\
\hline & 10 hours and above & 101 & 32.7 \\
\hline
\end{tabular}

According to Table- $1,34.3 \%$ of the students are female and $65.7 \%$ are male. When the age range is examined, $29.1 \%$ of the students $18-20$ age, $61,2 \%$ of the students $21-23$ age and $9.7 \%$ of them 24 and above. Considering they are trained in what grade the participants, $11 \%$ Class 1, 25.2\% Class 2, $29.1 \%$ Class 3 and $34.6 \%$ Class 4 . considering the weekly free time of the participants, $14,9 \%$ is $1-3$ hours, $28.8 \%$ is $4-6$ hours, $23.6 \%$ is $7-9$ hours and $32.7 \%$ is 10 hours and more.

Table 2. Participants' Free Time Preferences

\begin{tabular}{|c|c|c|c|c|}
\hline & Female & Male & Total & $\mathrm{t}$ \\
\hline & $\overline{\mathrm{X}} \mathrm{t} \pm \mathrm{SS}$ & $\overline{\mathrm{x}} \mathrm{t} \pm \mathrm{SS}$ & $\overline{\mathrm{x}} \mathrm{t} \pm \mathrm{SS}$ & \\
\hline Going to cafe etc. & $3.31 \pm 1.37$ & $3.10 \pm 1.35$ & $3.17 \pm 1.36$ & 1.236 \\
\hline Watching TV & $3.07 \pm 1.12$ & $3.13 \pm 1.20$ & $3.11 \pm 1.17$ & -0.456 \\
\hline Surf on Internet & $3.21 \pm 1.08$ & $3.36 \pm 1.14$ & $3.31 \pm 1.12$ & -1.114 \\
\hline Spending time on social media & $3.21 \pm 1.25$ & $3.29 \pm 1.23$ & $3.26 \pm 1.24$ & -0.508 \\
\hline Playing Computer Games & $2.56 \pm 1.41$ & $3.00 \pm 1.29$ & $2.85 \pm 1.34$ & $-2.744^{* *}$ \\
\hline Being With My Friends & $3.60 \pm 1.11$ & $3.45 \pm 1.08$ & $3.50 \pm 1.09$ & 1.153 \\
\hline Watching movie & $3.42 \pm 1.16$ & $3.50 \pm 1.04$ & $3.48 \pm 1.09$ & -0.596 \\
\hline Reading books & $3.65 \pm 1.12$ & $3.21 \pm 1.13$ & $3.36 \pm 1.15$ & $3.212^{* *}$ \\
\hline To participate in sports organizations / To do sports & $3.50 \pm 1.34$ & $3.47 \pm 1.29$ & $3.48 \pm 1.30$ & 0.232 \\
\hline
\end{tabular}

${ }^{* * P}<0.01$

When Table 2 is examined, the mean of the activities of the participants in their free time is given. Their preferred activities are in order of priority; 'To be with my friend', 'Watching movie', 'To participate in sports organizations / To do sports', 'Reading books', 'Surf on Internet', 'Spending time on social media', 'Going to Café etc.',
'Watching TV' and 'Playing Computer Games' has been ranked as.

In addition, when we examine the difference between free time preferences according to gender, "Playing computer games" has a mean score in favor of males $(\mathrm{t}=-2.774)$, while 'reading books' is higher in favor of female participants $(t=3.212)$.

Table 3. Aims of Use of Social Network Sites Scale Sub-Dimension Scores by Age Variable Kruskall Wallis Test

\begin{tabular}{|c|c|c|c|c|c|c|c|c|}
\hline & & Age & $\mathrm{n}$ & Order Average & $\mathrm{Sd}$ & $\mathrm{X} 2$ & $\mathrm{p}$ & \\
\hline \multirow{3}{*}{$\begin{array}{l}\text { Recognition } \\
\text { Publicity }\end{array}$} & $\mathrm{A}$ & 18-20 age & 90 & 164.78 & \multirow[t]{3}{*}{2} & \multirow[t]{3}{*}{6.383} & \multirow[t]{3}{*}{$0.041^{*}$} & \multirow[t]{3}{*}{$\mathrm{C}<\mathrm{A}$} \\
\hline & $\mathrm{B}$ & 21-23 age & 148 & 160.14 & & & & \\
\hline & $\mathrm{C}$ & 24 and above & 71 & 131.89 & & & & \\
\hline \multirow[t]{3}{*}{ Educational Usage } & A & 18-20 age & 90 & 161.11 & \multirow[t]{3}{*}{2} & \multirow[t]{3}{*}{0.722} & \multirow[t]{3}{*}{0.697} & \\
\hline & $\mathrm{B}$ & 21-23 age & 148 & 153.95 & & & & \\
\hline & $\mathrm{C}$ & 24 and above & 71 & 149.44 & & & & \\
\hline \multirow{3}{*}{$\begin{array}{l}\text { Social Communication } \\
\text { and } \\
\text { Purpose }\end{array}$} & $\mathrm{A}$ & 18-20 age & 90 & 156.81 & \multirow[t]{3}{*}{2} & \multirow[t]{3}{*}{2.574} & \multirow[t]{3}{*}{0.276} & \\
\hline & $\mathrm{B}$ & 21-23 age & 148 & 160.89 & & & & \\
\hline & $\mathrm{C}$ & 24 and above & 71 & 140.44 & & & & \\
\hline
\end{tabular}


Table 4. Aims of Use of Social Network Sites Scale Sub-Dimension Scores by Age Variable Kruskall Wallis Test

\begin{tabular}{|c|c|c|c|c|c|c|c|c|}
\hline & & Age & $\mathrm{n}$ & Order Average & $\mathrm{Sd}$ & $\mathrm{X} 2$ & $\mathrm{p}$ & \\
\hline \multirow{3}{*}{$\begin{array}{l}\text { Recognition } \\
\text { Publicity }\end{array}$} & $\mathrm{A}$ & 18-20 age & 90 & 164.78 & \multirow[t]{3}{*}{2} & \multirow[t]{3}{*}{6.383} & \multirow[t]{3}{*}{0.041} & \multirow[t]{3}{*}{$\mathrm{C}<\mathrm{A}$} \\
\hline & $\mathrm{B}$ & $21-23$ age & 148 & 160.14 & & & & \\
\hline & C & 24 and above & 71 & 131.89 & & & & \\
\hline \multirow[t]{3}{*}{ Educational Usage } & $\mathrm{A}$ & 18-20 age & 90 & 161.11 & \multirow[t]{3}{*}{2} & \multirow[t]{3}{*}{0.722} & \multirow[t]{3}{*}{0.697} & \\
\hline & B & $21-23$ age & 148 & 153.95 & & & & \\
\hline & $\mathrm{C}$ & 24 and above & 71 & 149.44 & & & & \\
\hline \multirow{3}{*}{$\begin{array}{l}\text { Social Communication } \\
\text { and } \quad \text { Interaction } \\
\text { Purpose }\end{array}$} & $\mathrm{A}$ & 18-20 age & 90 & 156.81 & \multirow[t]{3}{*}{2} & \multirow[t]{3}{*}{2.574} & \multirow[t]{3}{*}{0.276} & \\
\hline & $\mathrm{B}$ & 21-23 age & 148 & 160.89 & & & & \\
\hline & $\mathrm{C}$ & 24 and above & 71 & 140.44 & & & & \\
\hline
\end{tabular}

** $\mathrm{p}<0.05$

Table 4. As a result of the examination of the students participating in the study according to age variable, Social Network Sites Usage Purpose the'Recognition and Publicity Purpose' subscale differed significantly in favor of $18-20$ year old students.

Scale mean scores, it was found that

Table 5. Aims of Use of Social Network Sites Scale Sub-dimension Scores' by Class Variable Kruskall Wallis Test

\begin{tabular}{|c|c|c|c|c|c|c|c|c|}
\hline & & Class & $\mathrm{N}$ & $X$ & $\mathrm{sd}$ & $\mathrm{X} 2$ & $\mathrm{P}$ & \\
\hline \multirow{4}{*}{$\begin{array}{l}\text { Recognition } \\
\text { Publicity }\end{array}$} & A & 1. Class & 34 & 152.82 & \multirow[t]{4}{*}{3} & \multirow[t]{4}{*}{12.878} & \multirow[t]{4}{*}{$0.005^{* *}$} & \multirow[t]{4}{*}{$\mathrm{B}>\mathrm{All}$} \\
\hline & $B$ & 2. Class & 78 & 185.80 & & & & \\
\hline & $\mathrm{C}$ & 3. Class & 90 & 143.92 & & & & \\
\hline & $\mathrm{D}$ & 4. Class & 107 & 152.82 & & & & \\
\hline \multirow[t]{4}{*}{ Educational Usage } & A & 1. Class & 34 & 162.78 & \multirow[t]{4}{*}{3} & \multirow[t]{4}{*}{2.609} & \multirow[t]{4}{*}{0.456} & \\
\hline & $\mathrm{B}$ & 2. Class & 78 & 167.01 & & & & \\
\hline & $\mathrm{C}$ & 3. Class & 90 & 148.54 & & & & \\
\hline & $\mathrm{D}$ & 4. Class & 107 & 149.20 & & & & \\
\hline \multirow{4}{*}{$\begin{array}{l}\text { Social } \\
\text { and }\end{array}$} & $\mathrm{A}$ & 1. Class & 34 & 151.54 & \multirow[t]{4}{*}{3} & \multirow[t]{4}{*}{3.159} & \multirow[t]{4}{*}{0.368} & \\
\hline & B & 2. Class & 78 & 170.48 & & & & \\
\hline & $\mathrm{C}$ & 3. Class & 90 & 149.59 & & & & \\
\hline & D & 4. Class & 107 & 149.36 & & & & \\
\hline
\end{tabular}

${ }^{* *} \mathrm{p}<0.05$

Table 6. Aims of Use of Social Network Sites Scale Sub-dimensions Scores' T test by Monthly Income Variable

\begin{tabular}{|c|c|c|c|c|c|c|c|}
\hline & Monthly Income & $\mathrm{N}$ & $x$ & Ss & $\mathrm{Sd}$ & $\mathrm{T}$ & $\mathrm{P}$ \\
\hline \multirow[t]{2}{*}{ Recognition and Publicity } & 1500 and below & 212 & 2.8805 & 0.967 & \multirow[t]{2}{*}{307} & \multirow[t]{2}{*}{-2.867} & \multirow[t]{2}{*}{$0.004^{* *}$} \\
\hline & 1501 and above & 97 & 3.2268 & 1.023 & & & \\
\hline \multirow{2}{*}{ Educational Usage } & 1500 and below & 212 & 3.2005 & 0.867 & \multirow[t]{2}{*}{307} & \multirow[t]{2}{*}{0.043} & \multirow[t]{2}{*}{0.966} \\
\hline & 1501 and above & 97 & 3.1959 & 0.864 & & & \\
\hline \multirow{2}{*}{$\begin{array}{l}\text { Social Communication and } \\
\text { Interaction Purpose }\end{array}$} & 1500 and below & 212 & 3.3597 & 0.815 & \multirow[t]{2}{*}{307} & \multirow[t]{2}{*}{0.947} & \multirow[t]{2}{*}{0.973} \\
\hline & 1501 and above & 97 & 3.3632 & 0.822 & & & \\
\hline
\end{tabular}

${ }^{* *} \mathrm{p}<0.05$

When the Table 5 is examined, the students who participated in the research, it is determined that the mean scores of Social Networking Sites Purpose of Use Scale were significantly different in favor of the students studying at the Class 2 in the 'Recognition and Publicity Purpose'sub-dimension.

When the Table 6 is examined, students participating in the research based on the monthly income variable, the mean score of Social Networking Sites Purpose Scale was found to be significantly different in favor of the students who have 1501 or more income in the 'Recognition and Publicity Purpose' sub-dimension.

\section{DISCUSSION \& CONCLUSION}

In the social networks, which have recently increased rapidly in the world, it is possible for people to express themselves, to have fun with their stresses, and to unite in line with common goals or opinions. In this context, it is necessary to determine the purposes of social networking in young people and many institutions and organizations, especially higher education, in terms of creating activity, social domain and the necessary public spaces.

As a result of the study, while there is no difference according to the gender variable, the AUSNSC scale according to age variable is in favor of 18-20 age group in the sub-dimension of 'recognition and publicity purpose', according to the class variable, between the other classes in the subdimension of 'recognition and publicity purpose' in favor of Class 2, according to the monthly income variable, 'recognition and publicity purpose' subdimension yielded significant results in favor of 1501 and more income groups $(\mathrm{p}<0.05)$. 
In a study conducted by Filiz et al. (17) on Mehmet Akif Ersoy University students, it was observed that AUSNSC scale mean scores significantly changed in favor of Class 1 students. Although there is a significant difference in favor of Class 2 students, the AUSNSC Scale scores of the first year students are low. Similar results were obtained according to the age variable. This result shows that students who have just started university and who are looking for a chance to express themselves and who use social networks as a tool for this purpose are in low classes.

Akçayır (1) has linked the usage purpose of social networking with Maslow's needs hierarchy. Considering our results it can be said that, when individuals meet their physiological and basic needs, there are also tendencies to relieve the need for belonging through social networks (Table 2). As a matter of fact, when we look at the results, it can be thought that the way of expressing themselves are easier in the virtual environment considering that the university youth is composed of a multicultural structure. In addition to, the literature shows that males use higher levels of internet and their addiction levels are higher than females. In this respect, the table that questions the free time preferences coincides with the literature $(15,14)$

According to Martin (10), the use of the Internet primarily replaces the real life in social relations, so that users are caught in this bad cycle. At this point, the importance of interpersonal relations also comes into play. Studies show that there is a negative relationship between the degree of satisfaction obtained from interpersonal relationships in daily life and internet use. Individuals with disabilities in their social relationships often refer to the Internet to re-establish and maintain their personal relationships and replace the Internet with face-toface communication (2). These individuals may develop internet addiction to address interpersonal relationship requirements and create alternative social channels. Many people are trying to get the satisfaction they get from the interpersonal relations that they cannot find in their real life $(4,12)$. Individuals who cannot express themselves correctly or in a true way in daily life are trying to make meaningful relationships in internet environment $(16,11)$.

Research has some limitations. First of all, the individuals who created the sample were not selected by random sampling method; therefore they did not have the ability to represent. All of the sample is composed of university students, so the Turk J Sport Exe 2018; 20(3): 328 - 332 ๑ 2018 Faculty of Sport Sciences, Selcuk University differences between the students and the individuals working with the students could not be examined. When evaluating the findings, it will be a correct approach to consider these points and not to make generalizations.

\section{REFERENCES}

1. Akçayır G. Why Do Faculty Members Use or Not Use Social Networking Sites For Education?. Computers in Human Behavior, 2017, 71, 378-385.

2. Batıgün AD, Hasta D. İnternet Bağımlılı̆̆ı: Yalnızlık ve Kişilerarası Ilişki Tarzları Açısından Bir Değerlendirme. Anadolu Psikiyatri Dergisi, 2010, 11(3), 213-219.

3. Boyd DM, Ellison NB. Social Network Sites: Definition, History, And Scholarship. Journal Of Computer-Mediated Communication, 2007,13(1), 210-230.

4. Ceyhan AA. Predictors Of Problematic İnternet Use On Turkish University Students. Cyberpsychol Behav 2008; 11:363-366.

5. Deniz A. Sosyal A $\breve{g}$ Kullanımı Ve Sosyal Ağlarda Benlik Alg1sı: Muğla İli Örneği. Ege Üniversitesi Fen Bilimleri Enstitüsü, Bilgisayar Ve Öğretim Teknolojileri Anabilim Dalı, İzmir. 2012

6. Deperlioğlu Ö, Köse U., Web 2.0 Teknolojilerinin Eğitim Üzerindeki Etkileri Ve Örnek Bir Öğrenme Yaşantısı, Akademik Bilişim Konferansı, Muğla Üniversitesi. 2010.

7. http://stoweboyd.com/post/2325281845/are-you-ready-forsocial-software

8. Karal H, Kokoç M. Üniversite Öğrencilerinin Sosyal A ̆ğ Siteleri Kullanım Amaçlarını Belirlemeye Yönelik Bir Ölçek Geliştirme Çalışması. Türk Bilgisayar ve Matematik Eğitimi Dergisi, 2010, 1(3). 251-263

9. Mazman SG, , Sosyal Ağların Benimsenme Süreci Ve Eğitsel Bağlamda Kullanımı. (Yayınlanmış Yüksek Lisans Tezi). Hacettepe Üniversitesi, Ankara. 2009

10. Morahan-Martin JM. The Relationship Between Loneliness And İnternet Use And Abuse. Cyberpsychol Behav 1999; 2:431-439.

11. Özlü M , Öz N , Taşgın, E . (2018). Determination of Leisure Time Orientations in University Students, The Relationship Between Leisure Time Boredom Perceptions and Social Network Sites Usage Purposes. Turkish Journal of Sport and Exercise, 20 (2), 105-110.

12. Ridings CM, Gefen D. Virtual Community Attraction: Why People Hang Out Online. Journal of Computer-Mediated Communication, 2004, 10, 1.

13. Ucun K. Meslek Yüksek Okulu Öğrencilerinin Sosyal Ağlarda Facebook'u Genel Ve Mesleki Eğitimde Kullanım Amaçları. Sakarya Üniversitesi Fen Bilimleri Enstitüsü Elektronik Ve Bilgisayar Eğitimi Anabilim Dalı, Sakarya. 2012

14. Vaizoğlu SA, Aslan D, Görmüş U, Ünlügüzel G, Özemri S, Akkuş A, et al. Internet Use Among High School Students İn Ankara, Turkey. Saudi Med J 2004; 25:737-740.

15. Willoughby T. A Short-Term Longitudinal Study Of İnternet And Computer Game Use By Adolescent Boys And Girls: 
Prevalence, Frequency Of Use, And Psychosocial Predictors. Develop Psychol 2008; 44:195-204.

16. Yalçın C. Sosyolojik Bir Bakış Açısıyla İnternet. C.Ü. Sosyal Bilimler Dergisi 2003; 27:77-89.
17. Filiz O, Erol O, Dönmez F, Așkım Kurt A. BÖTE Bölümü Öğrencilerinin Sosyal A $\breve{g}$ Siteleri Kullanım Amaçları Ile Internet Bağımlılıkları Arasındaki Ilişkinin Incelenmesi. Journal of Instructional Technologies \& Teacher Education. 2014:3. 